\title{
[gw22-e0718] HIGH DENSITY LIPOPROTEIN INDUCES RATS MESENCHYMAL STEM CELLS PROLIFERATION THROUGH ACTIVATING PI3K-AKT PATHWAY
}

Jianfeng $\mathrm{Xu}^{1}$, Juying Qiann ${ }^{1}$ Xinxing $\mathrm{Xie}^{2}{ }^{2}$, Jianying $\mathrm{Ma}^{1}$, Li Lin², Mingqiang $\mathrm{Fu}^{1}$, Aijun Sun', Yunzeng Zou', Junbo Ge ${ }^{11}$ Zhongshan Hospital, Shanghai, China; ${ }^{2}$ Eastern Hospital, Hong kong, China

10.1136/heartjnl-2011-300867.67

Objective To explore the effect of high density lipoprotein (HDL) on the proliferation of mesenchymal stem cells (MSCs), and to elucidate the role of PI3K-Akt pathway in the potential regulation of it.

Methods MSCs were collected from the femora of SpragueDawley rats and were treated with HDL in different concentration $(0,20 \mathrm{ug} / \mathrm{ml}, 50 \mathrm{ug} / \mathrm{ml}, 100 \mathrm{ug} / \mathrm{ml})$ for $24 \mathrm{~h}$; and then were treated with HDL $(50 \mathrm{ug} / \mathrm{ml})$ for $24 \mathrm{~h}, 48 \mathrm{~h}$ and $72 \mathrm{~h}$, respectively. The proliferation of MSCs in each group was compared by Cell Counting Kit-8 (CCK-8) and BrdU cell proliferation assay. The expression of phosphorylation of Akt was evaluated by Western Blotting. LY294002, an inhibitor of PI3K, was used to down-regulate the activity of PI3K-Akt pathway.

Results The results showed that HDL induces markedly MSCs proliferation in time- and concentration-dependent manner. Akt phosphorylation was significantly increased by $2.35-, 4.52-$, and 5.89 -folds after simulation by $20 \mathrm{ug} / \mathrm{ml}, 50$ $\mathrm{ug} / \mathrm{ml}$ and $100 \mathrm{ug} / \mathrm{ml} \mathrm{HDL}$ for $24 \mathrm{~h}$ ( $\mathrm{p}$ value all $<0.05$ ). And when incubated with HLD $(50 \mathrm{ug} / \mathrm{ml})$, the phosphorylation of Akt was activated at $15 \mathrm{~min}$, and peaked at $60 \mathrm{~min}$ With the use of LY294002, the proliferation of MSCs was attenuated by $32 \%(26 \sim 40 \%$, p value $<0.05)$ when treated with HLD (50 ug/ $\mathrm{ml}$ ) for $24 \mathrm{~h}$.

Conclusion HDL improved the proliferation of MSCs in timeand concentration-dependant manner, and PI3K/Akt pathway was one of the underlying mechanisms involved in it. 